\title{
Editorial
}

\section{The Unsolved Relationship of Alcohol and Asthma}

\author{
Allan Linneberg ${ }^{\mathrm{a}-\mathrm{c}} \quad$ Arturo Gonzalez-Quintela ${ }^{\mathrm{d}}$ \\ ${ }^{a}$ Research Centre for Prevention and Health, The Capital Region of Denmark, Glostrup, and ${ }^{b}$ Department of \\ Clinical Experimental Research, Rigshospitalet, and ${ }^{\mathrm{C}}$ Department of Clinical Medicine, Faculty of Health and \\ Medical Sciences, University of Copenhagen, Copenhagen, Denmark; ${ }^{d}$ Department of Internal Medicine, \\ Complejo Hospitalario Universitario, Santiago de Compostela, Spain
}

Alcoholic drink consumption is a common lifestyle habit throughout the world. It is well known that a high consumption of alcohol increases the risk of several types of cancer. In contrast, alcohol's effects on the immune and respiratory systems are less recognized.

Alcohol consumption induces a strong suppression of the allergen-specific Th1-dependent response that renders alcoholics at markedly increased risk of respiratory bacterial infections such as tuberculosis [1] and pneumococcal disease [2]. Alcohol induces Th2 skewing of the immune response in terms of increased levels of Th2 cytokine and a marked increase in levels of serum total IgE $[3,4]$. The increased levels of serum total IgE consistently observed in alcoholics decreases following alcohol abstinence [5], supporting the idea that alcohol's increasing effect of serum total IgE is causal. Furthermore, Danish birth cohort studies found that maternal alcohol consumption during pregnancy was associated with increased levels of total IgE in the cord blood of the newborn child [6] and the risk of atopic dermatitis in early infancy [7], suggesting that alcohol influences the fetal immune system. A few epidemiological studies have suggested that increasing consumption of alcohol increases the risk of IgE sensitization against inhalant allergens, a well-documented biomarker of allergic respiratory disease, but studies have not been consistent [8-10]. Fur- thermore, high intakes of alcohol increase serum-specific IgE sensitization to cross-reactive carbohydrate determinants that may interfere with serum IgE determinations for the diagnostic evaluation of allergic patients [11].

Alcoholic drinks are commonly reported as triggers of hypersensitivity reactions of the skin and airways. In Asian populations these reactions are often particularly severe, resulting in alcohol-induced asthma and "Oriental flushing syndrome". The high risk of alcohol-induced reactions in these populations is due to a high frequency of a genetically determined decreased activity of acetaldehyde dehydrogenase 2 (ALDH2) that metabolizes acetaldehyde, the metabolite of alcohol [12]. Persons with this genetic variant develop asthma and flushing following the intake of alcohol, and these reactions are believed to be mediated through the immunological effects of acetaldehyde that peak following alcohol intake in individuals with a genetically determined low capacity to metabolize acetaldehyde [13]. Experimental studies seem to suggest that acetaldehyde has a histamine-releasing effect on mast cells in the airways and that this effect could represent the mechanism underlying the effects of alcohol on airways in ALDH2-deficient humans [14-18].

It has been assumed that the above mechanisms do not play a role in Caucasians where the ALDH2 slow-metabolizing variant is rare [19]. In spite of this, alcoholic drinks

\section{KARGER}

(c) 2016 S. Karger AG, Basel

E-Mail karger@karger.com

www.karger.com/iaa
Correspondence to: Prof. Allan Linneberg

Research Centre for Prevention and Health, Glostrup University Hospital Nordre Ringvej 57, Building 84/85

DK-2600 Glostrup (Denmark)

E-Mail allan.linneberg@ regionh.dk 
are very commonly reported triggers of hypersensitivity reactions in Caucasians [20-27]. Importantly, in Caucasian populations, alcoholic drink consumption is also considered a clinically important co-factor in food allergic reactions [21]. More than $30 \%$ of Caucasian asthmatics report that alcoholic drinks trigger asthma symptoms $[24,25]$. The mechanisms and clinical importance of these reactions are not known. Preservatives, such as sulphites, and the natural histamine content of wine have been proposed as the triggers of reactions following wine intake, but studies have so far not been able to confirm that these substances represent important underlying mechanisms of alcohol-induced reactions in Caucasians $[24,25,28]$. The fact that beer and spirits also are commonly reported as triggers of reactions would not fit the notion that sulphites and histamine are the offenders. Interestingly, one study did find high risk of alcohol-induced hypersensitivity reactions, including lower airway symptoms, in persons with a genetically determined fast metabolism of ethanol to acetaldehyde, as seen in carriers of the A allele of the alcohol dehydrogenase (ADH) $1 \mathrm{~b}$ variant rs1229984 [29]. That finding lends some support to the idea that asthmatic reactions following alcohol intake in Caucasians could be mediated via the same mechanism as in Asians, i.e., a histamine-releasing effect of ac- etaldehyde. However, there is probably a lot more to learn about both the mechanisms and the clinical relevance of alcohol-induced hypersensitivity reactions, particularly in Caucasians.

In this issue of the International Archives of Allergy and Immunology, Shimoda et al. [30] present data that improve our understanding of the mechanisms underlying alcohol-induced asthma. By using a novel mouse strain genetically deficient in ALDH2 they show that the likely mechanism of these reactions is a histamine-releasing effect of acetaldehyde. Furthermore, ALDH2-deficient mice show evidence of increased bronchial hyperresponsiveness (BHR) following alcohol intake. The effects of alcohol on BHR were not seen in another mouse strain genetically prone to dermatitis, although a small statistically non-significant elevation of BHR was seen following alcohol administration [30]. Thus, it would be of interest to more firmly confirm or refute an effect of alcohol on BHR in mice with a normal function of ALDH2 in future studies. Furthermore, it would be interesting to use the novel ALDH2-deficient mouse strain in further experiments, e.g., to study the effects of various drugs on the alcohol-induced effects seen in these mice, the effects of alcohol on other phenotypes, and the effects of longterm exposure.

\section{References}

1 Lonnroth K, Williams BG, Stadlin S, Jaramillo E, Dye C: Alcohol use as a risk factor for tuberculosis - a systematic review. BMC Public Health 2008;8:289.

2 Bhatty M, Pruett SB, Swiatlo E, Nanduri B: Alcohol abuse and Streptococcus pneumoniae infections: consideration of virulence factors and impaired immune responses. Alcohol 2011;45:523-539.

3 Linneberg A, Roursgaard M, Hersoug LG, Larsen ST: Effects of alcohol consumption on the allergen-specific immune response in mice. Alcohol Clin Exp Res 2008;32:553-556.

4 Gonzalez-Quintela A, Vidal C, Gude F: Alcohol-induced alterations in serum immunoglobulin E (IgE) levels in human subjects. Front Biosci 2002;7:e234-e244.

5 Gonzalez-Quintela A, Vidal C, Gude F: Alcohol, IgE and allergy. Addict Biol 2004;9:195204.

6 Bjerke T, Hedegaard M, Henriksen TB, Nielsen BW, Schiotz PO: Several genetic and environmental factors influence cord blood IgE concentration. Pediatr Allergy Immunol 1994;5:88-94.
7 Linneberg A, Petersen J, Gronbaek M, Benn CS: Alcohol during pregnancy and atopic dermatitis in the offspring. Clin Exp Allergy 2004;34:1678-1683.

8 Linneberg A, Petersen J, Nielsen NH, Madsen F, Frolund L, Dirksen A, Jorgensen T: The relationship of alcohol consumption to total immunoglobulin $\mathrm{E}$ and the development of immunoglobulin E sensitization: the Copenhagen Allergy Study. Clin Exp Allergy 2003; 33:192-198.

9 Gonzalez-Quintela A, Gude F, Boquete O, Rey J, Meijide LM, Suarez F, Fernandez-Merino MC, Perez LF, Vidal C: Association of alcohol consumption with total serum immunoglobulin E levels and allergic sensitization in an adult population-based survey. Clin Exp Allergy 2003;33:199-205.

10 Linneberg A, Friedrich N, Husemoen LL, Thuesen B, Gonzalez-Quintela A, Vidal C, Bodtger U, Johansen N, Drivsholm T: Incidence and remission of specific IgE aeroallergen sensitization from age of 40 to 60 years, and association with alcohol consumption. Int Arch Allergy Immunol 2010;151:142-148.
11 Gonzalez-Quintela A, Garrido M, Gude F, Campos J, Linneberg A, Lojo S, Vidal C: Sensitization to cross-reactive carbohydrate determinants in relation to alcohol consumption. Clin Exp Allergy 2008;38:152-160.

12 Takao A, Shimoda T, Kohno S, Asai S, Harda $S$ : Correlation between alcohol-induced asthma and acetaldehyde dehydrogenase- 2 genotype. J Allergy Clin Immunol 1998;101:576580.

13 Kawano T, Matsuse H, Kondo Y, Machida I, Saeki S, Tomari S, Mitsuta K, Obase Y, Fukushima C, Shimoda T, Kohno S: Acetaldehyde induces histamine release from human airway mast cells to cause bronchoconstriction. Int Arch Allergy Immunol 2004;134:233-239.

14 Shimoda T, Kohno S, Takao A, Fujiwara C, Matsuse H, Sakai H, Watanabe T, Hara K, Asai S: Investigation of the mechanism of alcohol-induced bronchial asthma. J Allergy Clin Immunol 1996;97:74-84.

15 Takao A, Shimoda T, Matsuse H, Mitsuta K, Obase Y, Asai S, Kohno S: Inhibitory effects of azelastine hydrochloride in alcohol-induced asthma. Ann Allergy Asthma Immunol 1999;82:390-394. 
16 Myou S, Fujimura M, Nishi K, Ohka T, Matsuda T: Aerosolized acetaldehyde induces histamine-mediated bronchoconstriction in asthmatics. Am Rev Respir Dis 1993;148:940943.

17 Myou S, Fujimura M, Bando T, Saito M, Matsuda T: Aerosolized acetaldehyde, but not ethanol, induces histamine-mediated bronchoconstriction in guinea-pigs. Clin Exp Allergy 1994;24:140-143.

18 Myou S, Fujimura M, Nishi K, Ohka T, Matsuda $\mathrm{T}$ : Inhibitory effect of terfenadine, a selective $\mathrm{H} 1$ histamine antagonist, on alcoholic beverage-induced bronchoconstriction in asthmatic patients. Eur Respir J 1995;8:619623.

19 Husemoen LL, Fenger M, Friedrich N, Tolstrup JS, Beenfeldt FS, Linneberg A: The association of $\mathrm{ADH}$ and $\mathrm{ALDH}$ gene variants with alcohol drinking habits and cardiovascular disease risk factors. Alcohol Clin Exp Res 2008;32:1984-1991.
20 Vally H, Thompson PJ: Alcoholic drinks and asthma. Clin Exp Allergy 2002;32:186-191.

21 Kanny G, Moneret-Vautrin DA, Flabbee J, Beaudouin E, Morisset M, Thevenin F: Population study of food allergy in France. J Allergy Clin Immunol 2001;108:133-140.

22 Ehlers I, Hipler UC, Zuberbier T, Worm M: Ethanol as a cause of hypersensitivity reactions to alcoholic beverages. Clin Exp Allergy 2002;32:1231-1235.

23 Vally H, Thompson PJ: Allergic and asthmatic reactions to alcoholic drinks. Addict Biol 2003;8:3-11.

24 Vally $\mathrm{H}$, de KN, Thompson PJ: Alcoholic drinks: important triggers for asthma. J Allergy Clin Immunol 2000;105:462-467.

25 Ayres JG, Clark TJ: Alcoholic drinks and asthma: a survey. Br J Dis Chest 1983;77:370-375.

26 Dahl R, Henriksen JM, Harving H: Red wine asthma: a controlled challenge study. J Allergy Clin Immunol 1986;78:1126-1129.
27 Linneberg A, Berg ND, Gonzalez-Quintela A, Vidal C, Elberling J: Prevalence of self-reported hypersensitivity symptoms following intake of alcoholic drinks. Clin Exp Allergy 2008;38:145-151

28 Kanny G, Gerbaux V, Olszewski A, Fremont S, Empereur F, Nabet F, Cabanis JC, MoneretVautrin DA: No correlation between wine intolerance and histamine content of wine. J Allergy Clin Immunol 2001;107:375-378.

29 Linneberg A, Gonzalez-Quintela A, Vidal C, Jorgensen T, Fenger M, Hansen T, Pedersen O, Husemoen LL: Genetic determinants of both ethanol and acetaldehyde metabolism influence alcohol hypersensitivity and drinking behaviour among Scandinavians. Clin Exp Allergy 2010;40:123-130.

30 Shimoda T, Obase Y, Matsuse H, Asai S, Iwanaga $\mathrm{T}$ : The pathogenesis of alcohol-induced airflow limitation in acetaldehyde dehydrogenase 2 (ALDH2)-deficient mice. Int Arch Allergy Immunol DOI: 10.1159/000452709. 